Please do not remove this page

RMIT

UNIVERSITY

Pre-treatments for removing colour from secondary effluent: Effectiveness and influence on membrane fouling in subsequent microfiltration

Nguyen, Sy; Roddick, Felicity

https://researchrepository.rmit.edu.au/esploro/outputs/9921861834401341/filesAndLinks?institution=61RMIT_INST\&index=null

Nguyen, S., \& Roddick, F. (2013). Pre-treatments for removing colour from secondary effluent: Effectiveness and influence on membrane fouling in subsequent microfiltration. Separation and Purification Technology, 103, 313-320. https://doi.org/10.1016/j.seppur.2012.10.011

Published Version: https://doi.org/10.1016/j.seppur.2012.10.011

Repository homepage: https://researchrepository.rmit.edu.au

(C) 2012 Elsevier B.V.

Downloaded On 2023/04/26 20:53:56 +1000

Please do not remove this page 
Thank you for downloading this document from the RMIT Research Repository.

The RMIT Research Repository is an open access database showcasing the research outputs of RMIT University researchers.

RMIT Research Repository: http://researchbank.rmit.edu.au/

\section{Citation:}

Nguyen, S and Roddick, F 2013, 'Pre-treatments for removing colour from secondary effluent: Effectiveness and influence on membrane fouling in subsequent', Separation and Purification Technology, vol. 103, pp. 313-320.

See this record in the RMIT Research Repository at:

http://researchbank.rmit.edu.au/view/rmit:18152

Version: Accepted Manuscript

Copyright Statement: (C) 2012 Elsevier B.V.

Link to Published Version:

http://dx.doi.org/10.1016/j.seppur.2012.10.011 


\title{
Pre-treatments for removing colour from secondary effluent: Effectiveness and influence on membrane fouling in subsequent microfiltration
}

\author{
S. T. Nguyen, F. A. Roddick* \\ School of Civil, Environmental and Chemical Engineering, RMIT University, GPO Box 2476, \\ Melbourne, Vic.3001, Australia
}

\begin{abstract}
The effects of different pre-treatments for colour removal on membrane fouling in the microfiltration (MF) of a coloured activated sludge (AS) effluent were investigated. It was found that a $80 \%$ colour removal target could be achieved by pre-treatment of the raw AS effluent with either ozone (10 mg $\mathrm{O}_{3} \mathrm{~L}^{-1}, 10$-minute contact time), a powdered activated carbon (150 $\mathrm{mg} \mathrm{L}^{-1}, 30$-minute contact time), or a strong base anion exchange resin $\left(10 \mathrm{~mL} \mathrm{~L}^{-1}, 20\right.$-minute contact time $)$. Of these pre-treatments, ozonation was the only method that resulted in a reduction in membrane fouling. The other two methods, while they showed high removals of dissolved organic matter, did not affect the membrane flux. The changes in the membrane foulants due to the pre-treatments were determined and were used to explain the differences in the membrane flux. The results showed that pre-treatments for fouling reduction in MF of secondary effluent should target the biopolymers (which contained polysaccharides and proteins) in the effluent.
\end{abstract}

Keywords: Anion exchange resin; membrane fouling; microfiltration; ozone; powdered activated carbon

\section{Introduction}

\subsection{Background}

Australia has experienced long-term and severe droughts over the last decade and is expected to face these events more frequently in the future [1]. As a result, water authorities are seeking alternative water sources to meet the increasing demand due to increasing population. It is recognised that reusing municipal wastewater will significantly increase Australian water

Abbreviations: AER, anion exchange resin; AS, activated sludge; HS, humic substance; UMFI, unified membrane fouling index

* Corresponding author. Tel.: +61 39925 2080; fax: +61 399253746

E-mail address: felicity.roddick@rmit.edu.au (F.A. Roddick). 
availability [2]. However, secondary effluents produced at some municipal wastewater treatment plants (WWTPs) have a yellow colour, which can be a deterrent in promoting effluent reuse. For such treatment plants, the integration of a pre-treatment for colour removal and a microfiltration (MF) process is a potential strategy for the production of treated effluents low in colour, pathogens and turbidity. The aim of this study was to identify the pre-treatment methods for removing $75-80 \%$ of the true colour (i.e., colour after filtration through a $0.45 \mu \mathrm{m}$ membrane) from a brownish yellow secondary effluent collected from a municipal WWTP in Victoria (Australia) and to investigate the effect of these pre-treatments on membrane fouling in subsequent MF. The results obtained would be beneficial to other WWTPs with effluents of similar characteristics.

Currently, the WWTP under consideration treats sewage via 4 stages: preliminary, primary, and secondary (activated sludge, AS) treatment followed by disinfection. The brownish yellow colour of the AS effluent has been a major concern, as it may limit customers' willingness to purchase and reuse the effluent. Therefore, the treatment plant has aimed to reduce the true colour of this effluent (which can range over 65-120 Pt-Co units) by approximately $80 \%$, so that the final effluent would have a true colour of 15-25 Pt-Co units, which appears almost colourless. This target has been achieved in trials by the application of ozone at a dose of $10 \mathrm{mg} \mathrm{L}^{-1}$ to the raw effluent for 10 minutes. Another potential solution is to treat the AS effluent with anion exchange resins (AERs) since humic substances (HS), the colour-imparting compounds in surface waters and wastewaters, are negatively charged, and so should be removed by the resins. Colour-causing compounds can also be removed by adsorption using powdered activated carbon (PAC). These two treatment methods, however, have not been tested for this wastewater.

\subsection{Membrane fouling in microfiltration (MF) and ultrafiltration (UF) of water and municipal wastewater}

Membrane fouling can be defined as the accumulation of contaminants on the membrane which causes a reduction in the permeate flux through the membrane. There are many ways in which a membrane is fouled, including [3]:

(i) Deposition of particulates and suspended solids on the membrane (particulate fouling). This type of fouling can be mitigated by membrane backwashing and/or air scrubbing;

(ii) Precipitation of dissolved organic matter (DOM) on the membrane surface or in membrane pores (organic fouling); 
(iii) Accumulation of biological growth in the system and/or its attachment to the membrane (biofouling). Extracellular polymeric substances (EPS) produced by the attached microorganisms can form a viscous slimy gel, which retards the permeate flow;

(iv) Accumulation of inorganic precipitates (e.g., metal hydroxides) and "scales" on membrane surface or within membrane pores.

The major cause of fouling of MF and UF membranes is organic fouling, resulting from the accumulation of DOM in the feedwater in the membrane pores or on the membrane surface. Biofouling may occur in long-term operation when chemical cleaning do not result in complete inactivation of micro-organisms in the membrane modules [3]. Fouling is normally classified as reversible and irreversible fouling. Foulants in hydraulically reversible fouling generally exist as a cake layer on the membrane surface and can be removed by hydraulic cleaning such as backwashing. Irreversible fouling is caused by the adsorption or pore plugging of solutes in and within the membrane pores [4].

Membrane fouling during MF and UF of natural waters and wastewaters has been studied extensively over the last few decades. However, researchers have reported different materials as being responsible for organic fouling and different effects of feed pre-treatments on membrane fouling. Many found that the high molecular weight (MW) compounds, including polysaccharides and proteins, in water and wastewater were the major membrane foulants whereas HS made a minor contribution to fouling [5-8]. Others indicated that HS played an important role in causing membrane fouling [9-12]. Kim and Dempsey [13] found that organic acids, which contained humic acid, fouled MF and UF membranes more severely than any other components (including colloidal organic matter and hydrophilic base/neutrals) in a municipal wastewater. Factors which potentially contributed to the difference in these findings include differences in the characteristics of the water and the membranes and differences in the methods used to identify the foulants.

\subsection{Effects of pre-treatments with ozone, AERs, and PAC on fouling in low pressure membrane} filtration

Ozonation has been used widely in drinking water production to remove colour, tastes and odours. However, the application of ozone in wastewater treatment is still quite limited [14]. Previous studies found that ozonation reduced membrane fouling in MF and UF of secondary effluent by breaking down the membrane foulants to lower MW components [15, 16]. However, Zhu et al. [17] found that ozonation pre-treatment worsened membrane fouling in dead-end MF of a secondary 
effluent with a ceramic membrane. They attributed this phenomenon to the increase in the concentration of large organic molecules after ozonation and suggested this increase may have resulted from the lysis of the bacteria in the effluent.

Powdered activated carbon (PAC) has been used for the removal of taste, odour, dissolved organic matter (DOM), and synthetic organic chemicals from drinking water. Many water treatment plants use MF or UF membranes to separate the spent PAC, microorganisms, and other particulate matter, from the finished water [18]. Both beneficial and adverse effects of PAC pre-treatment on membrane fouling have been reported. For example, Carroll et al. [19] observed that although PAC adsorption removed nearly $70 \%$ of the DOM in Moorabool River water (Victoria, Australia), the pre-treatment had little impact on the permeate flux in dead-end MF. On the other hand, Dialynas and Diamadopoulos [20] found that PAC pre-treatment worsened membrane fouling in UF of a municipal wastewater and attributed this phenomenon to the increased hydrodynamic resistance caused by the PAC cake on the membrane surface. Improvement in MF and UF flux performance resulting from pre-treatment with PAC was observed with surface water by Konieczny and Klomfas [21] and with municipal wastewater by Haberkamp et al. [22] and Lee et al. [23]. The differences in these findings may be due to differences in the PAC used (e.g., pore size and particle size) and differences in characteristics of the feeds and the membranes. They also illustrate the need to investigate the effect of this pre-treatment on membrane fouling for the AS effluent under consideration.

AERs have been found very effective in removing DOM and colour-causing compounds in surface waters [24]. Many have the advantage of easy regeneration. However, similar to pre-treatment with ozone and PAC, the removal of DOM by AERs does not always result in fouling reduction in MF and UF. For example, fouling reduction by adsorption pre-treatment with magnetic ion exchange $\left(\right.$ MIEX $\left.^{\circledR}\right)$ and IRA-958 resins was observed by Zhang et al. [25] and Kim and Dempsey [13], while no effect on fouling was observed by Humbert et al. [7].

\section{Materials and methods}

\subsection{Wastewater sources}

\subsubsection{Raw AS effluent and ozonated effluent}

Samples of the raw and ozonated AS effluent were taken from the WWTP and transported to RMIT University laboratory. At the treatment plant, the ozonated effluent was produced by treating the 
raw effluent with ozone at $10 \mathrm{mg} \mathrm{O}_{3} \mathrm{~L}^{-1}$ for 10 minutes. The ozone transfer efficiency was consistently greater than $96 \%$. Table 1 shows the characteristics of the raw AS effluent.

Table 1. Characteristics of the raw AS effluent at the WWTP (data collected from September 2008 to September 2011)

\subsubsection{Anion exchange pre-treatment}

This was accomplished using a commercial strong base AER in a jar tester (PB-700, Phipps \& Bird). The characteristics of the AER are shown in Table 2. Initial jar tests were conducted with AER doses of 5 and $10 \mathrm{~mL}$ resin $\mathrm{L}^{-1}$ to identify the dose which gave a colour reduction of approximately $80 \%$. After adding the resin to the raw AS effluent, the jar contents were stirred at $100 \mathrm{rpm}$ for 20 minutes. The resin was then allowed to settle for 10 minutes and the supernatant was decanted and retained for MF tests.

Table 2. Characteristics of the AER used in this study

As in practice the AER is normally used to treat approximately 1500 bed volumes of water before it is regenerated, the resin was reused without regeneration until the total volume of the effluent treated reached 1500 bed volumes. The combined treated AS effluent at each particular dose could be considered as being equivalent to that produced from plant operation. The colour removals at resin doses of $5 \mathrm{~mL} \mathrm{~L}^{-1}$ and $10 \mathrm{~mL} \mathrm{~L}^{-1}$ were $65 \%$ and $78 \%$, respectively. The AS effluent sample treated with $10 \mathrm{~mL} \mathrm{AER} \mathrm{L}^{-1}$ was used in the MF tests.

\subsubsection{PAC adsorption}

Acticarb PS1300 (Activated Carbon Technologies) was selected for its high adsorption activity and high colour removal (as per manufacturer's information). The characteristics of the PAC are shown in Table 3.

Table 3. Characteristics of the PAC used in the study

PAC adsorption of HS, the major colour-causing compounds in waters and municipal wastewaters, may take several days to reach equilibrium [26]. However, such a long contact time is not available in the WWTP. Therefore, in this study, the contact time for PAC adsorption was limited to 30 minutes. The adsorption was carried out in a jar tester with a stirrer speed of $100 \mathrm{rpm}$. Preliminary 
tests showed that for a contact time of 30 minutes, a PAC dose of $150 \mathrm{mg} \mathrm{L}^{-1}$ was needed to achieve $80 \%$ colour removal.

\subsection{Analytical methods}

The dissolved organic carbon (DOC) concentration and UV absorbance at $254 \mathrm{~nm}\left(\mathrm{UVA}_{254}\right)$ were measured with a Sievers 5310C TOC analyser and a Unicam UV/vis spectrophotometer, respectively. The fluorescence excitation-emission matrices (EEMs) were obtained with a PerkinElmer Luminescence Spectrometer (model LS 50) at an excitation (Ex) and emission (Em) wavelength range of 200-550 $\mathrm{nm}$. The samples (except the MF permeates) were pre-filtered through $0.45 \mu \mathrm{m}$ cellulose acetate membranes prior to these measurements.

A Hach spectrophotometer (model DR/4000) was used to determine the true colour in Pt-Co units at $455 \mathrm{~nm}$ (according to Standard Method $2120 \mathrm{C}$ [27]) and residual ozone concentration in the ozonated AS effluent (using the indigo method [28]). As expected, no residual ozone was detected in the ozonated effluent and hence did not affect the MF flux.

The apparent molecular weight distributions (AMWDs) of the samples were determined using liquid chromatography with organic carbon detection (LC-OCD) at the University of New South Wales, Sydney, Australia. The instrument was an LC-OCD system (Model 8, DOC-Labor) equipped with an organic carbon detector (OCD) and a UV detector (UVD, responds to UVabsorbing compounds at $254 \mathrm{~nm}$ ). The detailed description and working principles of this system were published elsewhere [29]. The software program ChromCalc (DOC-Labor, Karlsruhe) was used for data acquisition and processing. The chromatograms were divided into 5 different areas corresponding to biopolymers (which contained polysaccharides and proteins, MW >> 20,000 Da), HS (MW = 1,000-20,000 Da), building blocks (MW = 300-500 Da), low MW organic acids and low MW HS (MW < $350 \mathrm{Da}$ ), and low MW neutrals (MW < $350 \mathrm{Da}$ ) [29]. The samples (except the MF permeates) were pre-filtered through $0.45 \mu \mathrm{m}$ cellulose acetate membranes and diluted 1:3 with Milli-Q water prior to the analysis. The dilution was necessary as samples subjected to LC-OCD analysis should contain less than $5 \mathrm{mg} \mathrm{C} \mathrm{L}^{-1}$ [29]. The sample injection volume was $1000 \mu \mathrm{L}$.

The pore size distribution of the PAC was obtained from nitrogen gas adsorption data at $77 \mathrm{~K}$ with a Micromeritics Accelerated Surface Area and Porosimetry (ASAP) 2000 unit. Prior to the measurement, the sample was degassed at $250{ }^{\circ} \mathrm{C}$ overnight under vacuum. The total surface area of the PAC was calculated using the Brunauer-Emmett-Teller (BET) method. Volumes of micropores 
and mesopores were obtained from Barrett-Joyner-Halenda $(\mathrm{BJH})$ pore area and pore volume analysis.

\subsection{Filtration experiments and data analysis}

Filtration experiments were carried out using four hollow-fibre MF membrane modules (XUNP003, Pall Corporation). Each module comprised 32 polyvinylidene fluoride (PVDF) fibres (inner diameter $=1.0 \mathrm{~mm}$, outer diameter $=0.8 \mathrm{~mm}$, nominal pore size $=0.1 \mu \mathrm{m}$ ) potted in a polyether sulfone shell, giving a total filtration area (outside-in mode) of $0.0082 \mathrm{~m}^{2}$. According to the manufacturer, this membrane had a hydrophobic surface. The virgin modules had similar pure water fluxes (differences were within 5\%). The fouled membranes were regenerated by soaking in a mixture of $\mathrm{NaOH}(0.025 \mathrm{~N})$ and $\mathrm{NaOCl}(200 \mathrm{ppm}$ available chlorine) (prepared with Milli-Q water) at $35^{\circ} \mathrm{C}$ for 2 hours. This chemical cleaning (recommended by the manufacturer) allowed full recovery of the membrane pure water flux. The cleaned membranes (after having 2 L of Milli-Q water passed through them to remove residual chlorine) were then used in further tests. No deterioration in the DOC removal and colour removal as a result of chemical cleaning was observed.

The filtration tests were conducted in dead-end outside-in mode (no retentate stream) and at a constant pressure of $70 \mathrm{kPa}$ (regulated using compressed nitrogen gas). These conditions were selected based on those used by Adham et al. [18] and Howe et al. [30] in bench-scale MF of surface water. A top-loading electronic balance (Explorer, Ohaus, accuracy $\pm 0.01 \mathrm{~g}$ ) was used to record the permeate mass, which was logged by a computer. These data were used to calculate the permeate flux $(J)$ through the membranes. Prior to the filtration tests, the membrane modules had 2 L of Milli-Q water passed through them to remove preservatives and determine the pure water flux $\left(J_{0}\right)$. The temperature of the feeds was $22 \pm 1^{\circ} \mathrm{C}$. MF tests were run in duplicate and the flux curves obtained for each sample were almost superimposed. The results presented in this paper were supported by those obtained from previous experiments with another batch of samples.

Howe et al. [30] indicated that fouling of virgin membranes tended to be more severe than fouling of hydraulically backwashed membranes. As a result, flux data obtained from filtration with virgin membranes may not be representative for the entire filtration process in which filtration is done with backwashed membranes for the majority of the time. In MF and UF of secondary effluents, backwashing is normally carried out every $15-30$ minutes [6, 31]. Therefore, in this study, MF tests were conducted in both single-cycle and multi-cycle modes. While single-cycle MF was a simple 
method to compare the effect of the different pre-treatments on MF flux, results obtained from multi-cycle tests provided information regarding hydraulically irreversible fouling in a filtration protocol similar to that used in WWTPs.

In the single-cycle tests, the raw, ozonated, AER-treated and PAC-treated effluent samples were filtered through the MF membrane until a cumulative specific permeate volume $(v)$ of $200 \mathrm{~L} \mathrm{~m}^{-2}$ was collected. This took approximately 100 minutes for the raw effluent. MF tests were also conducted with the raw and treated effluent samples after pre-filtration through $1.0 \mu \mathrm{m}$ glass-fibre filters (GF/B, Whatman). These tests allowed flux comparison without interference from PAC particles and residual AER.

In the multi-cycle tests, six MF cycles, each lasting 20 minutes and followed by backwashing for 1 minute, were carried out. Backwashing was accomplished by passing the permeate in the reverse direction (i.e., inside-out) at the operating pressure $(70 \mathrm{kPa})$. The pure water fluxes of the membranes were measured with Milli-Q water at the beginning of each cycle and were used to calculate the unified membrane fouling index (UMFI) for hydraulically irreversible fouling [32].

\section{Results and discussion}

3.1. Effects of ozonation, AER, and PAC pre-treatments on the characteristics of the raw AS effluent The characteristics of the raw, ozonated, AER-treated and PAC-treated AS effluent are shown in Table 4 . The $80 \%$ colour removal target was achieved by treating the raw AS effluent with ozone at $10 \mathrm{mg} \mathrm{L}^{-1}$, the AER at $10 \mathrm{~mL} \mathrm{~L}^{-1}$ or Acticarb PS1300 at $150 \mathrm{mg} \mathrm{L}^{-1}$. However, whereas AER and PAC treatments removed approximately $37 \%$ and $57 \%$ of the DOC from the raw AS effluent, respectively, ozonation caused a small increase in the DOC concentration. Also, the reduction in the $\mathrm{UVA}_{254}$ after ozonation (42\%) was significantly lower than after adsorption with the AER (63\%) and the PAC (74\%). These observations can be attributed to the difference in the mechanisms of colour removal of the pre-treatments: whereas ozone reduced the effluent colour by partial oxidation of HS [33], the AER and the PAC removed colour by adsorbing HS molecules [24, 26].

Table 4. Characteristics of the raw and variously treated AS effluent

The LC-OCD chromatograms of the raw and pre-treated AS effluent samples (Fig. 1) provided insights into the effects of the pre-treatments on the dissolved effluent organic matter (EfOM). The 
DOC concentrations of the different organic components were calculated from the areas under the peaks [29] and are shown in Table 5.

Fig 1. AMWDs of the raw, ozonated, AER-treated, and PAC-treated effluents

(a) UV detector response (254 nm), (b) Organic carbon detector response

(The dotted lines define the areas under the peaks)

Table 5. Effect of ozonation and the adsorption pre-treatments with and without MF on the concentrations of dissolved EfOM components (in $\mathrm{mg} \mathrm{C} \mathrm{L}^{-1}$ ) as determined by LC-OCD

Colour removal by ozonation resulted from the oxidation of colour-imparting compounds (i.e., compounds with conjugated $\mathrm{C}-\mathrm{C}$ double bonds) in the raw AS effluent to colourless materials. The oxidation process, however, did not lead to a reduction in DOC. The small increase in the DOC concentration after ozonation was attributed to DOC released from the breakdown of colloidal organic matter to lower MW compounds [34, 35] and/or breakdown of micro-organisms (e.g., bacteria, algae, protozoa). The LC-UVD signals (Fig. 1 (a)) indicated that ozonation resulted in the partial breakdown of all EfOM components in the raw effluent. The breakdown in the molecular structures of HS was responsible for the colour reduction $[33,36]$. A small proportion of HS was broken down to building block molecules, low MW acids, and low MW neutrals (Fig.1 (b) in which the HS peak of the ozonated sample was slightly taller and narrower than the HS peak of the raw effluent, and Table 5). This was consistent with the results reported by previous researchers, who found that ozone oxidised humic acid to give low MW substances, such as carboxylic acids (e.g., formic, acetic, oxalic, and glyoxylic acids) and aldehydes [33, 36, 37]. The DOC concentration of biopolymers did not reduce after ozonation, although the breakdown of their molecular structures was evident in Fig. 1 (a).

In the PAC pre-treatment, EfOM adsorbed onto the PAC and this resulted in a large reduction in the DOC concentration of the effluent. The EfOM components adsorbed on the PAC included HS, building blocks, and low MW neutrals. The forces keeping the EfOM molecules attached to the PAC may include [38] (i) electrostatic attraction between PAC surface and EfOM, (ii) hydrophobic attraction between graphitic carbon surface and hydrophobic portions of EfOM molecules, (iii) hydrogen bonding between functional groups on EfOM and those on the carbon surface, and (iv) $\pi$ interactions between the carbon surface and the aromatic EfOM. The simultaneous operation of these mechanisms, and more importantly, the presence of both mesopores $(2-50 \mathrm{~nm})$ and 
micropores $(<2 \mathrm{~nm})$ may explain why the PAC removed not only building blocks and low MW neutrals but also HS. At the same dosage and contact time, another PAC product (provided by Tiwest Sales Australia) with a similar surface area $\left(1427 \mathrm{~m}^{2} \mathrm{~g}^{-1}\right)$, a lower mesopore volume $(0.33$ $\left.\mathrm{cm}^{3} \mathrm{~g}^{-1}\right)$ and a higher micropore volume $\left(0.25 \mathrm{~cm}^{3} \mathrm{~g}^{-1}\right)$ than the PAC used in this study (Acticarb PS1300) gave only 48\% colour removal. This observation suggested that PAC with a higher mesopore volume is likely to be more effective in removing HS, which is consistent with the size of mesopores $(2-50 \mathrm{~nm})$ and HS molecules (aquatic fulvic acids generally have an average diameter of $2 \mathrm{~nm}$ whereas aquatic humic acids are larger molecules [12]). Building blocks and low MW neutrals were likely to adsorb in both mesopores and micropores. Approximately $75 \%$ of the building blocks and $65 \%$ of low MW neutral compounds in the raw AS effluent were removed by the PAC treatment.

The AER adsorbed a larger proportion of HS than the PAC. However, it was not as effective as the PAC in removing building blocks and low MW neutrals (Fig.1 and Table 5). The higher selectivity of the AER than the PAC for HS was attributed to the electrostatic attraction between the resin and the negatively charged HS molecules. During the adsorption test, it was noticed that the colour removal of the AER reduced with the passage of increasing volume of the treated sample. The colour of the effluent after the first 100 bed volumes was $8 \mathrm{Pt}$-Co units whereas after treatment of 1500 bed volumes, the colour of the combined treated effluent was $22 \mathrm{Pt}$-Co units due to increasing saturation of the adsorption sites with increasing volume.

\subsection{Effect of the pre-treatments on membrane fouling}

The flux data for the raw, ozonated, and PAC and AER-treated samples are shown in Fig. 2. Ozonation was the only pre-treatment that resulted in improved MF flux. PAC and AER adsorption neither reduced nor worsened membrane fouling. MF of the $1.0 \mu \mathrm{m}$ pre-filtered samples gave similar results (Fig. A.1. in the Appendix), indicating that the PAC particles and residual AER particles had little effect on the flux and therefore the difference in the flux of the non-pre-filtered samples was due to the difference in their dissolved EfOM contents.

Fig. 2. Flux data for MF of the raw and variously treated AS effluent samples

The EfOM components responsible for membrane fouling were identified and the effect of the pretreatments on the foulants was investigated using LC-OCD analysis. The high retention (i.e., the difference between the concentration in the feed and that in the permeate) of biopolymers (MW >> 
20,000 Da) and HS (MW = 1,000-20,000 Da) by the MF membrane (Fig. 3 and Table 5) was consistent with previous studies which demonstrated that these components were potential foulants in MF and UF of surface water and secondary effluent [5-12]. HS were probably retained by hydrophobic attraction to the hydrophobic membrane $[3,39]$. The removal of HS also led to the removal of true colour by the membrane (feed colour $=100 \mathrm{Pt}-\mathrm{Co}$ units, permeate colour $=86 \mathrm{Pt}$ Co units). Biopolymers (which included polysaccharides and proteins), due to their large molecular sizes, were likely to foul the membrane by blocking the pores and then forming a cake layer on the membrane surface $[3,39]$.

Fig. 3. LC-OCD chromatograms of the raw effluent and the MF permeates

The role of biopolymers and HS in causing membrane fouling was verified by examining the flux data for the raw and the pre-treated secondary effluent in combination with the LC-OCD data. Of the pre-treatments investigated, ozonation was the only pre-treatment that affected biopolymers (i.e., partially oxidised these compounds, Fig. 1) and reduced membrane fouling (Fig. 2). Adsorption with the PAC and the AER, while removed a large proportion of HS, did not remove biopolymers from the raw effluent, and did not affect the membrane flux. Furthermore, the flux improvement after ozonation was associated with an increase in the amount of biopolymers permeated the membrane (Table 5). These results indicated that biopolymers were the major contributor to membrane fouling.

The inability of the PAC to remove biopolymers may be due to: (i) the preferential adsorption of the HS and the low MW compounds on the PAC led to the saturation of the PAC with these molecules and therefore no adsorption sites were available for the biopolymers and/or (ii) the larger size of the biopolymer molecules than the pores of the PAC. The low removal of polysaccharides and proteins by the AER was very likely due to their lack of negatively charged functional groups at the sample $\mathrm{pH}[7,29]$.

The biopolymers in the raw, AER-treated, and PAC-treated effluents had similar fouling potentials, as indicated by the similar retention by the membrane (Fig. 3 and Table 5). The membrane retained a lower amount of HS in the ozonated $\left(0.4 \mathrm{mg} \mathrm{C} \mathrm{L}^{-1}\right)$, AER-treated $\left(0.5 \mathrm{mg} \mathrm{C} \mathrm{L}^{-1}\right)$ and PAC-treated $\left(0.8 \mathrm{mg} \mathrm{C} \mathrm{L}^{-1}\right)$ effluents than in the raw effluent $\left(1.0 \mathrm{mg} \mathrm{C} \mathrm{L}^{-1}\right)$ (Table 5), indicating that the HS remaining in the pre-treated effluents probably had a lower fouling potential than the HS in the raw effluent. However, for the adsorption pre-treatments, this did not result in any improvement in the 
MF flux. Therefore, it can be concluded that HS made a minor contribution to membrane fouling compared with biopolymers and pre-treatments for fouling reduction in MF of secondary effluent should target the biopolymers.

Information obtained from fluorescent EEMs (Fig. 4) provided some further insight into the characteristics of the compounds involved in the fouling of the membranes. According to Chen et al. [40], regions I (Ex/Em: 220-270 nm/280-330 nm) and II (Ex/Em: 220-270 nm/330-380 nm) in the EEMs correspond to the fluorescence response of tyrosine and tryptophane (and/or proteins containing these aromatic amino acids). Regions III (Ex/Em: 220-270 nm/380-550 nm), IV (Ex/Em: 270-440 nm/280-380 nm), and V (Ex/Em: 270-440 nm/380-550 nm) can be matched with fulvic acid-like material, soluble microbial products (SMPs), and humic acid-like material, respectively. The total intensity of fluorescence response (or EEM volume) in the individual regions of the EEMs was computed using the fluorescence regional integration method [40]. As seen in Fig. 4, MF of the raw effluent led to marginal reductions in tryptophan-related compounds and SMPs (which include biopolymers) and larger reductions in humic acid-like and fulvic acid-like compounds. Hence the biopolymers contributing to fouling were mostly non-fluorescent.

Fig. 4. Fluorescence EEM volumes of the raw and variously treated effluent samples

(inset: EEM of the raw effluent)

Adsorption with the AER removed substantial amounts of fulvic acid-like and humic acid-like matter, and some tryptophan-related compounds and SMPs. Adsorption with the PAC and ozonation led to large reductions in the fluorescence of all five compound categories. However, the rejection of tryptophan-related compounds and SMPs by the MF membrane was lower for the ozonated effluent than the other two samples. This can be explained as ozonation causing the breakage of bonds, leading to a reduction in molecular size of these compounds and thus reducing fouling of the membrane. The fluorescent EfOM components removed by the AER and the PAC did not appear to play a role in fouling.

The flux data obtained from multi-cycle MF of the raw and variously treated effluent are shown in Fig. 5. Here the reciprocal of the normalised flux $\left(J_{0} / J\right)$ was plotted against specific permeate volume $(v)$ [32]. The results show that ozonation reduced the rate of flux decline not only for the virgin membrane, but also for the hydraulically backwashed membrane. As expected, adsorption pre-treatments with the AER and the PAC had no significant impact on the flux performance of the 
virgin and the backwashed membranes. The increase in the value of $J_{0} / J$ with successive cycles indicated the accumulation of residual fouling which was not removed by backwashing.

Fig. 5. Flux data for multi-cycle MF of the raw and variously treated effluent

Values of UMFI for hydraulically irreversible fouling for MF of the samples were calculated using the two-point approach [32]. Because these MF tests were run in the constant-pressure mode instead of the constant-flux mode, the UMFIs were calculated based on the filtration time rather than on the permeate volume as in [32]. The values of $v$ and $J_{0} / J$ at the beginning of the first cycle $\left(v=0, J_{0} / J=\right.$ 1) and the sixth cycle were used in the calculation. For each sample, the slope of the straight line connecting these two points was the UMFI for hydraulically irreversible fouling [32]. These values for the raw, AER-treated and PAC-treated effluents were approximately $0.011 \mathrm{~m}^{2} \mathrm{~L}^{-1}$, whereas it was $0.0064 \mathrm{~m}^{2} \mathrm{~L}^{-1}$ for the ozonated effluent. The reduction in hydraulically irreversible fouling by ozonation indicates the opportunity to reduce the frequency of membrane chemical cleaning and therefore increase the membrane lifetime.

\subsection{Potential effect on membrane biofouling}

It should be pointed out that although ozonation pre-treatment reduced membrane fouling by EfOM (i.e., organic fouling), the increase in the concentrations of the low MW compounds after ozonation may increase the risk of biofouling of the MF membrane, particularly when complete inactivation of micro-organisms in the membrane module is not achieved with chlorine enhanced backwash. This is because these organic compounds can be easily utilised by micro-organisms in the effluent for their growth and reproduction [41, 42]. PAC adsorption, on the other hand, may reduce membrane biofouling in MF, as it removed a significant proportion of building blocks and low MW neutrals from the raw effluent. Since the AER was not effective for removing these compounds, it is likely that this pre-treatment would not have any significant effect on membrane biofouling.

\section{Conclusions}

The effects of different pre-treatments for colour removal on membrane fouling in MF of a secondary effluent were investigated. Although a colour removal of $80 \%$ could be achieved with ozonation $\left(10 \mathrm{mg} \mathrm{O}_{3} \mathrm{~L}^{-1}\right)$ or adsorption with the AER $\left(10 \mathrm{~mL} \mathrm{~L}^{-1}\right)$ or the PAC $\left(150 \mathrm{mg} \mathrm{L}^{-1}\right)$, of these only ozonation reduced membrane fouling. The reduction in fouling resulted from the breakdown in the molecular structures of the membrane foulants (polysaccharides, proteins, and HS). Ozone oxidised a small proportion of the humic substances to give building blocks, low MW acids, and 
low MW neutrals, which may increase the risk of membrane biofouling. Pre-treatment with the PAC and the AER neither reduced nor increased fouling, as the proportion of the EfOM removed by the PAC and the AER made no significant contribution to membrane fouling. However, PAC adsorption may reduce biofouling as it removed a significant proportion of the low MW compounds from the raw AS effluent. The results of this study showed that pre-treatment of secondary effluent to reduce organic fouling of MF membranes should target the biopolymers.

\section{Acknowledgement}

The authors wish to acknowledge the Australian Research Council (ARC) for financially supporting this study (project number LP0776870). The anonymous reviewers are thanked for their constructive feedbacks, which help to improve the quality of this manuscript.

\section{References}

[1] Australian Government - Bureau of Meteorology, An assessment of the impact of climate change on the nature and frequency of exceptional climatic events, Canberra, Australia, 2008.

[2] Victorian Government - Department of Sustainability and Environment, Victorian Government White Paper: Our Water Our Future - Securing Our Water Future Together, Victoria, Australia, 2004.

[3] C. Liu, S. Caothien, J. Hayes, T. Caothuy, T. Otoyo, T. Ogawa, Membrane chemical cleaning: from art to science, in: Proceedings of the AWWA Water Quality Technology Conference, March 4-7, 2001, San Antonio, Texas, USA.

[4] A. Zularisam, A. Ismail, R. Salim, Behaviours of natural organic matter in membrane filtration for surface water treatment - a review, Desalination 194 (2006) 211-231.

[5] N. Lee, G. Amy, J.-P. Croué, H. Buisson, Identification and understanding of fouling in low pressure membrane (MF/UF) filtration by natural organic matter (NOM), Water Res. 38 (2004) $4511-4523$.

[6] C. Laabs, G. Amy, M. Jekel, Understanding the size and character of fouling-causing substances from effluent organic matter (EfOM) in low-pressure filtration, Environ. Sci. Technol. 40 (2006) 4495-4499.

[7] H. Humbert, H. Gallard, V. Jacquemet, J.-P. Croué, Combination of coagulation and ion exchange for the reduction of UF fouling properties of a high DOC content surface water, Water Res. 41 (2007) 3803-3811. 
[8] J. Haberkamp, M. Ernst, U. Böckelmann, U. Szewzyk, M. Jekel, Complexity of ultrafiltration membrane fouling caused by macromolecular dissolved organic compounds in secondary effluents, Water Res. 42 (2008) 3153-3161.

[9] W. Yuan, A.L. Zydney, Humic acid fouling during microfiltration, J. Membr. Sci. 157 (1999) $1-12$.

[10] K.L. Jones, C.R. O'Melia, Ultrafiltration of protein and humic substances: effect of solution chemistry on fouling and flux decline, J. Membr. Sci. 193(2001) 163-173.

[11] H.K. Shon, S. Vigneswaran, I.S. Kim, J. Cho, H.H. Ngo, Fouling of ultrafiltration membrane by effluent organic matter: A detailed characterization using different organic fractions in wastewater, J. Membr. Sci. 278 (2006), 232-238.

[12] I. Sutzkover-Gutman, D. Hasson, R. Semiat, Humic substances fouling in ultrafiltration process, Desalination 261 (2010) 218-231.

[13 H.C. Kim, B.A. Dempsey, Removal of organic acids from EfOM using anion exchange resins and consequent reduction of fouling in UF and MF, J. Membr. Sci. 364 (2010) 325-330.

[14] M.A. Oneby, C.O. Bromley, J.H. Borchardt, D.S. Harrison, Ozone treatment of secondary effluent at U.S. municipal wastewater treatment plants, Ozone Sci. Eng. 32 (2010) 43-55.

[15] S. Lee, K. Lee, W.M. Wan, Y. Choi, Comparison of membrane permeability and a fouling mechanism by pre-ozonation followed by membrane filtration and residual ozone in membrane cells, Desalination 178 (2005) 287-294.

[16] X. Wang, L. Wang, Y. Liu, W. Duan, Ozonation pretreatment for ultrafiltration of the secondary effluent, J. Membr. Sci. 287 (2007) 187-191.

[17] H. Zhu, X. Wen, M. Noguchi, Y. 2009, Membrane fouling in the reclamation of secondary effluent with an ozone-membrane hybrid system, Sep. Sci. Technol. 44 (2009) 121-130.

[18] S.S. Adham, K.-P. Chiu, S.G. Lehman, K. Howe, A. Marwah, C. Mysore, J. Clouet, Z. DoQuang, O. Cagnard, Optimization of Membrane Treatment for Direct and Clarified Water Filtration, AWWA Research Foundation, Colorado, 2006.

[19] T. Carroll, S. King, S.R. Gray, B.A. Bolto, N.A. Booker, The fouling of microfiltration membranes by NOM after coagulation treatment, Water Res. 34 (2000) 2861-2868.

[20] E. Dialynas, E. Diamadopoulos, Integration of immersed membrane ultrafiltration with coagulation and activated carbon adsorption for advanced treatment of municipal wastewater, Desalination 230 (2008) 113-127.

[21] K. Konieczny, G. Klomfas, Using activated carbon to improve natural water treatment by porous membranes, Desalination 147 (2002) 109-116. 
[22] J. Haberkamp, A.S. Ruhl, M. Ernst, M. Jekel, Impact of coagulation and adsorption on DOC fractions of secondary effluent and resulting fouling behaviour in ultrafiltration, Water Res. 41 (2007) 3794-3802.

[23] C.W. Lee, S.D. Bae, S.W. Han, L.S. Kang, Application of ultrafiltration hybrid membrane processes for reuse of secondary effluent, Desalination 202 (2007) 239-246.

[24] B. Bolto, D. Dixon, R. Eldridge, S. King, K. Linge, Removal of natural organic matter by ion exchange, Water Res. 36 (2002) 5057-5065.

[25] R. Zhang, S. Vigneswaran, H.H. Ngo, H. Nguyen, Magnetic ion exchange (MIEX®) resin as a pre-treatment to a submerged membrane system in the treatment of biologically treated wastewater, Desalination 192 (2006) 296-302.

[26] R.S. Summers, P.V. Roberts, Activated carbon adsorption of humic substances I. Heterodisperse mixtures and desorption, J. Colloid and Interface Sci. 122 (1988) 367-381.

[27] Standard Methods for the Examination of Water \& Wastewater, twenty-first ed., American Public Health Association (APHA), Washington DC, 2005.

[28] Hach Company, DR/4000 Spectrophotometer Procedures Manuals, eleventh ed., Hach Company, USA, 2003.

[29] S.A. Huber, A. Balz, M. Abert, W. Pronk, Characterisation of aquatic humic and non-humic matter with size-exclusion chromatography - organic carbon detection - organic nitrogen detection (LC-OCD-OND), Water Res. 45 (2011) 879-885.

[30] K.J. Howe, A. Marwah, K.-P. Chiu, S.S. Adham, Effect of membrane configuration on benchscale MF and UF fouling experiments, Water Res. 41 (2007) 3842-3849.

[31] Water Environment Federation, Membrane Systems for Wastewater Treatment, first ed., McGraw-Hill, New York, 2006.

[32] H. Huang, T. Young, J. Jacangelo, Novel approach for the analysis of bench-scale, low pressure membrane fouling in water treatment, J. Membr. Sci. 334 (2009) 1-8.

[33] V. Camel, A. Bermond, The use of ozone and associated oxidation processes in drinking water treatment, Water Res. 32 (1998) 3208-3222.

[34] G.-S. Wang, S-Y. Pai, Ozonation of dissolved organic matter in biologically treated wastewater effluents, Ozone Sci. Eng. 23 (2001) 351-358.

[35] S.G. Lehman, L. Liu, Application of ceramic membranes with pre-ozonation for treatment of secondary wastewater effluent, Water Res. 43 (2009) 2020-2028.

[36] N. Takahashi, T. Nakai, Y. Satoh, Y. Katoh, Ozonolysis of humic acid and its effect on decoloration and biodegradability, Ozone Sci. Eng. 17 (1995) 511-525. 
[37] U. von Gunten, Review-Ozonation of drinking water: Part I. Oxidation kinetics and product formation, Water Res. 37 (2003) 1443-1467.

[38] G. Newcombe, C. Hepplewhite, M. Bjelopavlic, C. David, Research Report 16 - Optimisation of Adsorption Processes, Water Quality Research Australia, Adelaide, Australia, 2008.

[39] H. Yamamura, K. Kimura, Y. Watanabe, Mechanism involved in the evolution of physically irreversible fouling in microfiltration and ultrafiltration membranes used for drinking water treatment, Environ. Sci. Technol. 41 (2007) 6789-6794.

[40] W. Chen., P. Westerhoff, J.A. Leenheer, K. Booksh, Fluorescence excitation-emission matrix regional integration to quantify spectra for dissolved organic matter, Environ. Sci. Technol. 37 (2003) 5701-5710.

[41] D. van der Kooij, A.A.M. Hijnen, J.C. Kruithof, The effects of ozonation, biological filtration and distribution on the concentration of easily assimilable organic carbon (AOC) in drinking water, Ozone Sci. Eng. 11 (1989) 297-311.

[42] I.T. Miettinen, T. Vartiainen, T. Nissinen, T. Tuhkanen, P.J. Martikainen, Microbial growth in drinking waters treated with ozone, ozone/hydrogen peroxide or chlorine, Ozone Sci. Eng. 20 (1998) 303-315.

Table 1. Characteristics of the raw AS effluent from the WWTP (data collected from September 2008 to September 2011)

\begin{tabular}{ll}
\hline Parameter & Value \\
\hline $\mathrm{pH}$ & $7.2-7.8$ \\
Total DOC $\left(\mathrm{mg} \mathrm{L}^{-1}\right)$ & $10.5-15.8$ \\
$\mathrm{UVA}_{254}\left(\mathrm{~cm}^{-1}\right)$ & $0.33-0.43$ \\
$\mathrm{SUVA}\left(\mathrm{L} \mathrm{m}^{-1} \mathrm{mg}^{-1}\right)$ & $2.4-3.8$ \\
True colour $(\mathrm{Pt}-\mathrm{Co}$ unit $)$ & $65-118$ \\
Turbidity $(\mathrm{NTU})$ & $1.9-5.6$ \\
Total suspended solids $\left(\mathrm{mg} \mathrm{L}^{-1}\right)$ & $2.1-7.0$ \\
Conductivity $\left(\mu \mathrm{S} \mathrm{cm}^{-1}\right)$ & $944-1060$ \\
\hline
\end{tabular}

Table 2. Characteristics of the AER used in this study

\begin{tabular}{ll}
\hline Functional group & Quaternary ammonium \\
Matrix & Polyacrylic \\
Mean pore size $(\mathrm{nm})$ & 45 \\
Particle size $(\mu \mathrm{m})$ & $150-180$ \\
Charge capacity $\left(\right.$ meq $\left.\mathrm{mL}^{-1}\right)$ & 0.52
\end{tabular}


Table 3. Characteristics of the PAC used in the study

\begin{tabular}{ll} 
Origin & Coal \\
Iodine number $\left(\mathrm{mg} \mathrm{g}^{-1}\right)$ & $>1200$ \\
Average particle size $(\mu \mathrm{m})$ & $20-30$ \\
Micropore $(<2 \mathrm{~nm})$ volume $\left(\mathrm{cm}^{3} \mathrm{~g}^{-1}\right)$ & 0.15 \\
Mesopore $(2-50 \mathrm{~nm})$ volume $\left(\mathrm{cm}^{3} \mathrm{~g}^{-1}\right)$ & 0.52 \\
Surface area $\left(\mathrm{m}^{2} \mathrm{~g}^{-1}\right)$ & 1429 \\
\hline
\end{tabular}

Table 4. Characteristics of the raw and variously treated AS effluent

\begin{tabular}{|c|c|c|c|c|}
\hline Parameter & Raw & Ozonated & $\begin{array}{c}\text { AER-treated } \\
\left(10 \mathrm{~mL} \mathrm{AER} \mathrm{L}^{-1}\right)\end{array}$ & PAC-treated \\
\hline $\mathrm{pH}$ & 7.8 & 7.7 & 7.7 & 7.8 \\
\hline $\mathrm{DOC}\left(\mathrm{mg} \mathrm{L}^{-1}\right)$ & 15.1 & 15.5 & 9.5 & 6.5 \\
\hline $\mathrm{UVA}_{254}\left(\mathrm{~cm}^{-1}\right)$ & 0.389 & 0.227 & 0.144 & 0.101 \\
\hline $\operatorname{SUVA}\left(\mathrm{m}^{-1} \mathrm{mg}^{-1} \mathrm{~L}\right)$ & 2.58 & 1.46 & 1.52 & 1.54 \\
\hline True colour (Pt-Co units) & 100 & 22 & 22 & 21 \\
\hline Turbidity (NTU) & 1.9 & 1.8 & Not measured & Not measured \\
\hline
\end{tabular}


Table 5. Effect of ozonation and the adsorption pre-treatments with and without $\mathrm{MF}$ on the concentrations of dissolved EfOM components (in $\mathrm{mg} \mathrm{C} \mathrm{L}^{-1}$ ) as determined by LC-OCD

\begin{tabular}{lcccccc}
\hline Sample & $\begin{array}{c}\mathrm{CDOC}^{\mathrm{a}} \\
\left(\mathrm{mg} \mathrm{L}^{-1}\right)\end{array}$ & $\begin{array}{c}\text { Biopolymers }^{\mathrm{b}} \\
\left(\mathrm{mg} \mathrm{L}^{-1}\right)\end{array}$ & $\begin{array}{c}\mathrm{HS}^{\mathrm{c}} \\
\left(\mathrm{mg} \mathrm{L}^{-1}\right)\end{array}$ & $\begin{array}{c}\text { Building }_{\text {blocks }^{\mathrm{d}}} \\
\left(\mathrm{mg} \mathrm{L}^{-1}\right)\end{array}$ & $\begin{array}{c}\text { Low MW } \\
\mathrm{acids}^{\mathrm{e}} \\
\left(\mathrm{mg} \mathrm{L}^{-1}\right)\end{array}$ & $\begin{array}{c}\text { Low MW } \\
\text { neutrals }^{\mathrm{f}} \\
\left(\mathrm{mg} \mathrm{L}^{-1}\right)\end{array}$ \\
\hline Raw & 13.9 & 1.3 & 8.0 & 2.4 & n.d. & 2.2 \\
Ozonated & 14.3 & 1.4 & 7.6 & 2.7 & 0.2 & 2.4 \\
AER-treated & 8.5 & 1.4 & 2.5 & 2.4 & n.d. & 2.2 \\
PAC-treated & 6.4 & 1.3 & 3.6 & 0.7 & n.d. & 0.8 \\
Raw + MF & 11.6 & 0.2 & 7.0 & 2.2 & n.d. & 2.2 \\
Ozonated + MF & 13.1 & 0.7 & 7.2 & 2.7 & 0.2 & 2.3 \\
AER-treated + MF & 6.8 & 0.3 & 2.0 & 2.3 & n.d. & 2.2 \\
PAC-treated + MF & 4.5 & 0.2 & 2.8 & 0.7 & n.d. & 0.8 \\
\hline
\end{tabular}

${ }^{\mathrm{a}}$ Chromatographic Dissolved Organic Carbon, i.e., DOC detected by the LC column

${ }^{\mathrm{b}}$ Proteins, protein-like material, polysaccharides, polysaccharide-like material, amino sugars, $\mathrm{MW}=20,000-100,000 \mathrm{Da}$ ${ }^{\mathrm{c}} \mathrm{MW}=1,000-20,000 \mathrm{Da}$

${ }^{\mathrm{d}}$ Breakdown products of HS, MW $=300-500 \mathrm{Da}$

${ }^{\mathrm{e}}$ Monoprotic organic acids, $\mathrm{MW}<350 \mathrm{Da}$

${ }^{\mathrm{f}}$ Include mono-oligosaccharides, alcohols, aldehydes, ketones, MW $<350 \mathrm{Da}$

${ }^{*}$ n.d. $=$ not detected 

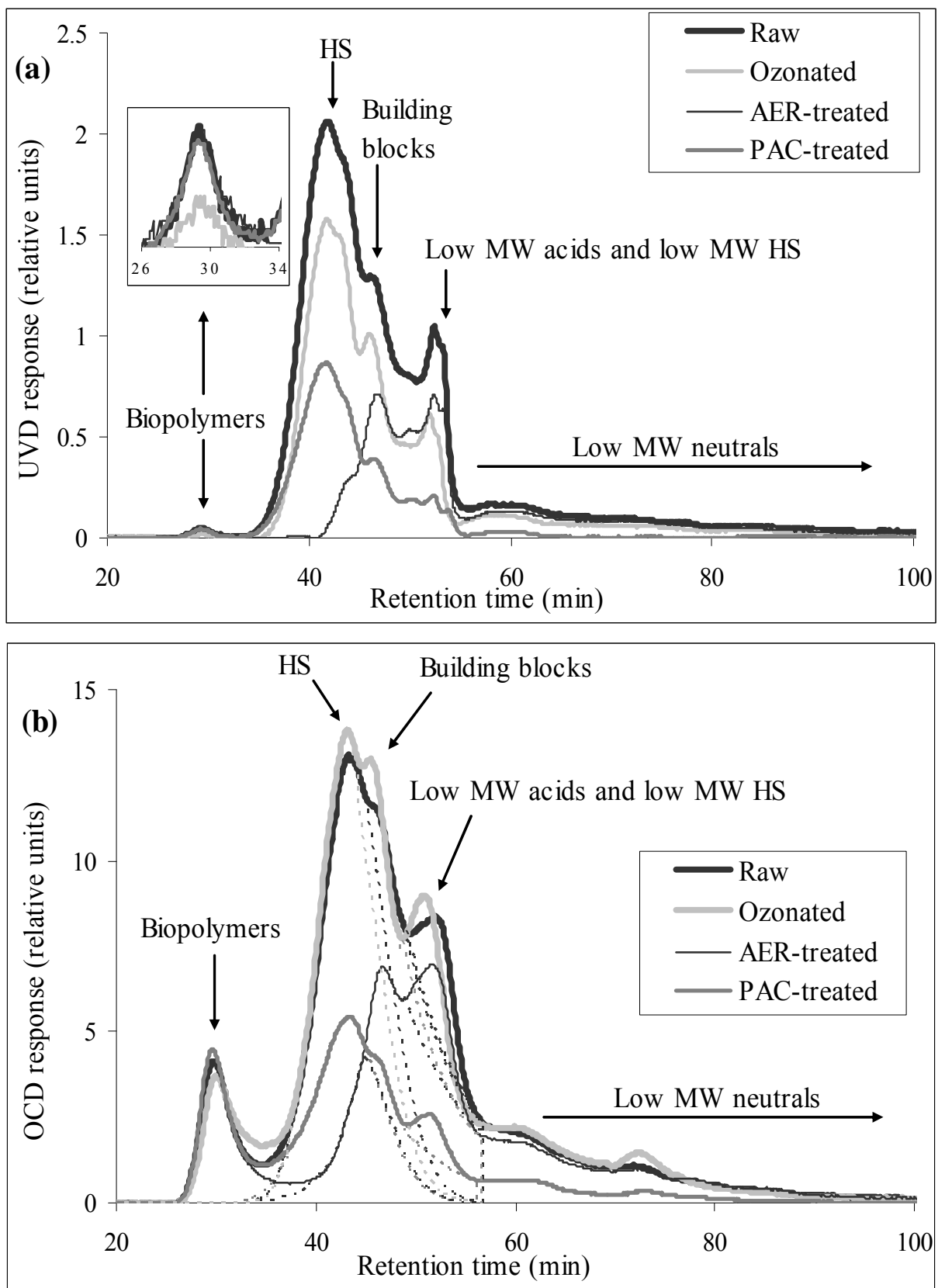

Fig. 1. AMWDs of the raw, ozonated, AER-treated, and PAC-treated effluents (a) UV detector response (254 nm), (b) Organic carbon detector response (The dotted lines define the areas under the peaks) 


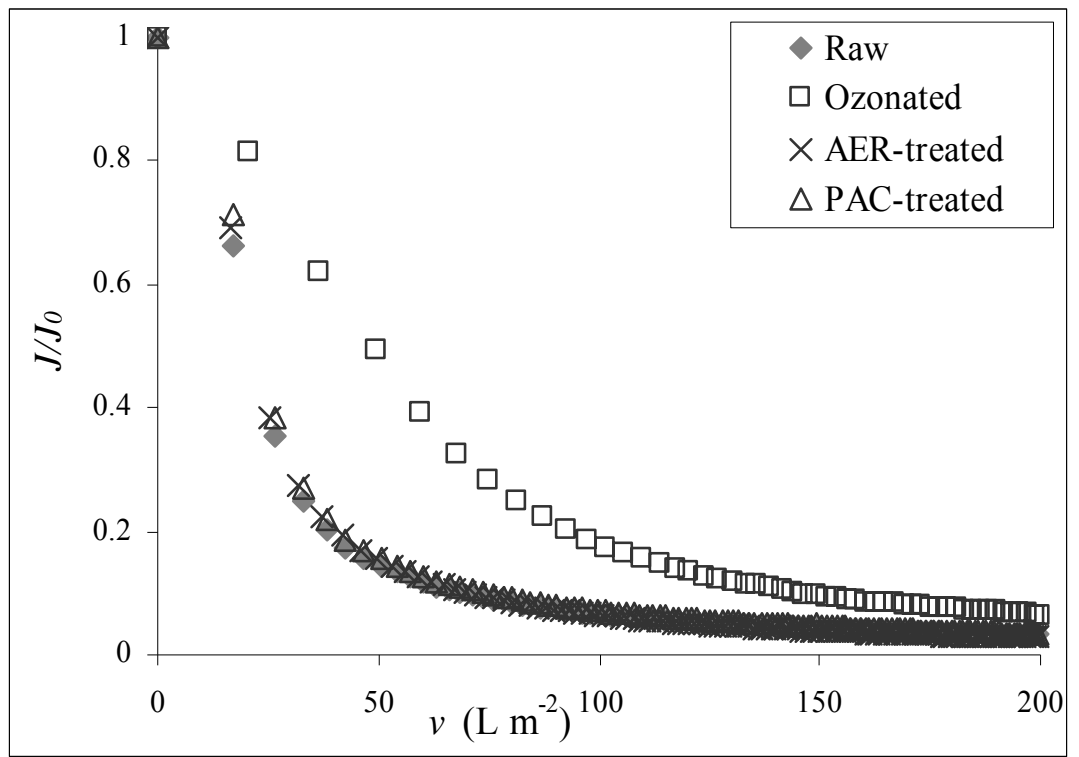

Fig. 2. Flux data for MF of the raw and variously treated AS effluent samples

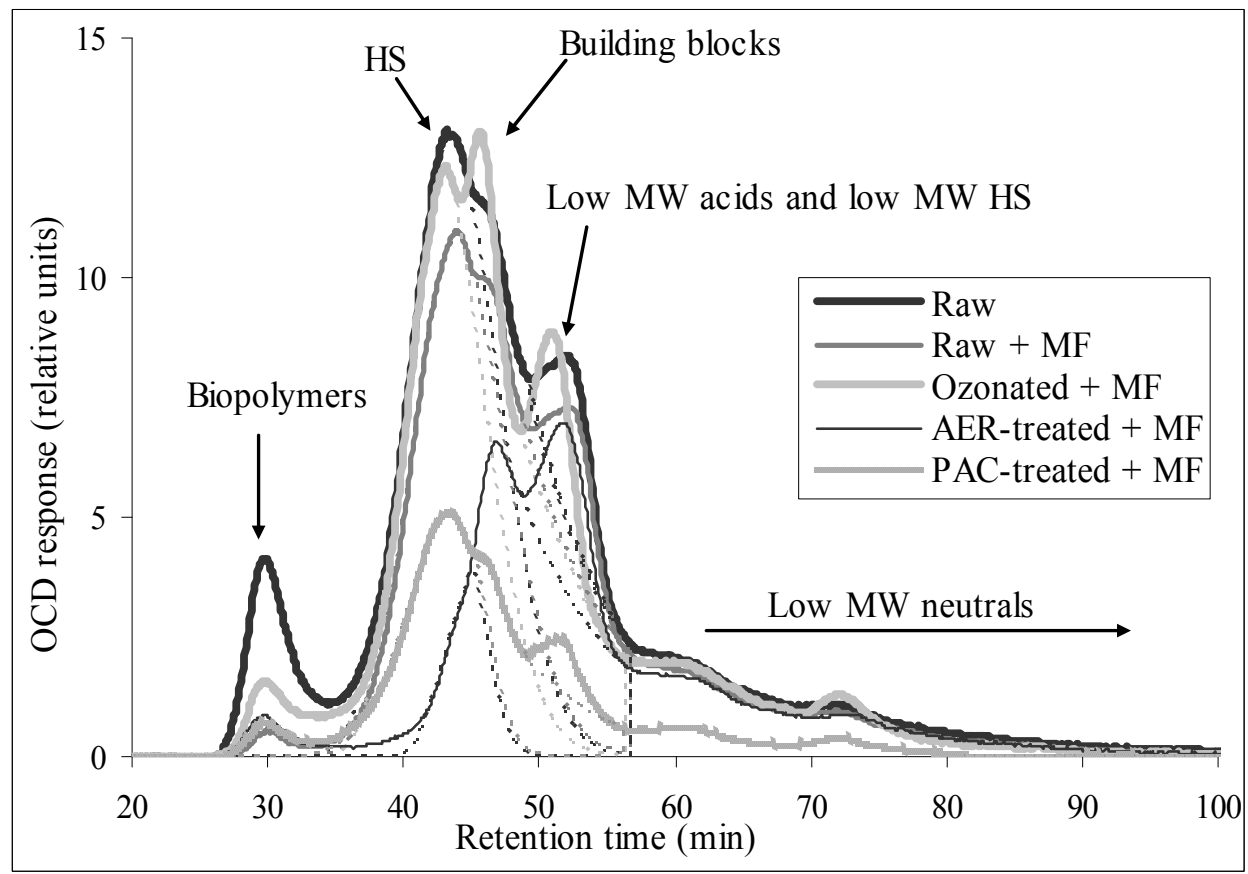

Fig. 3. LC-OCD chromatograms of the raw effluent and the MF permeates 


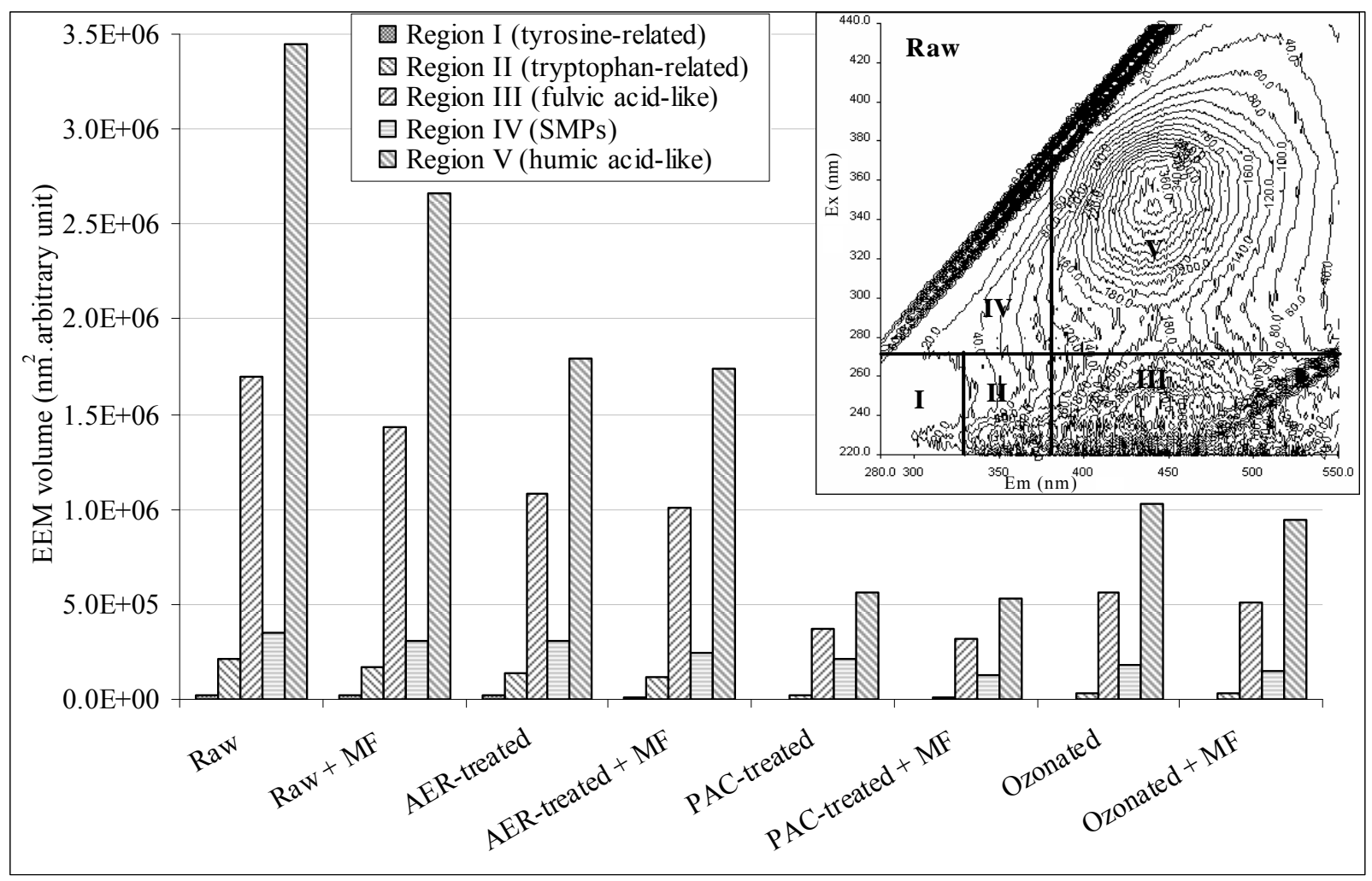

Fig. 4. Fluorescence EEM volumes of the raw and variously treated effluent samples (inset: EEM of the raw effluent)

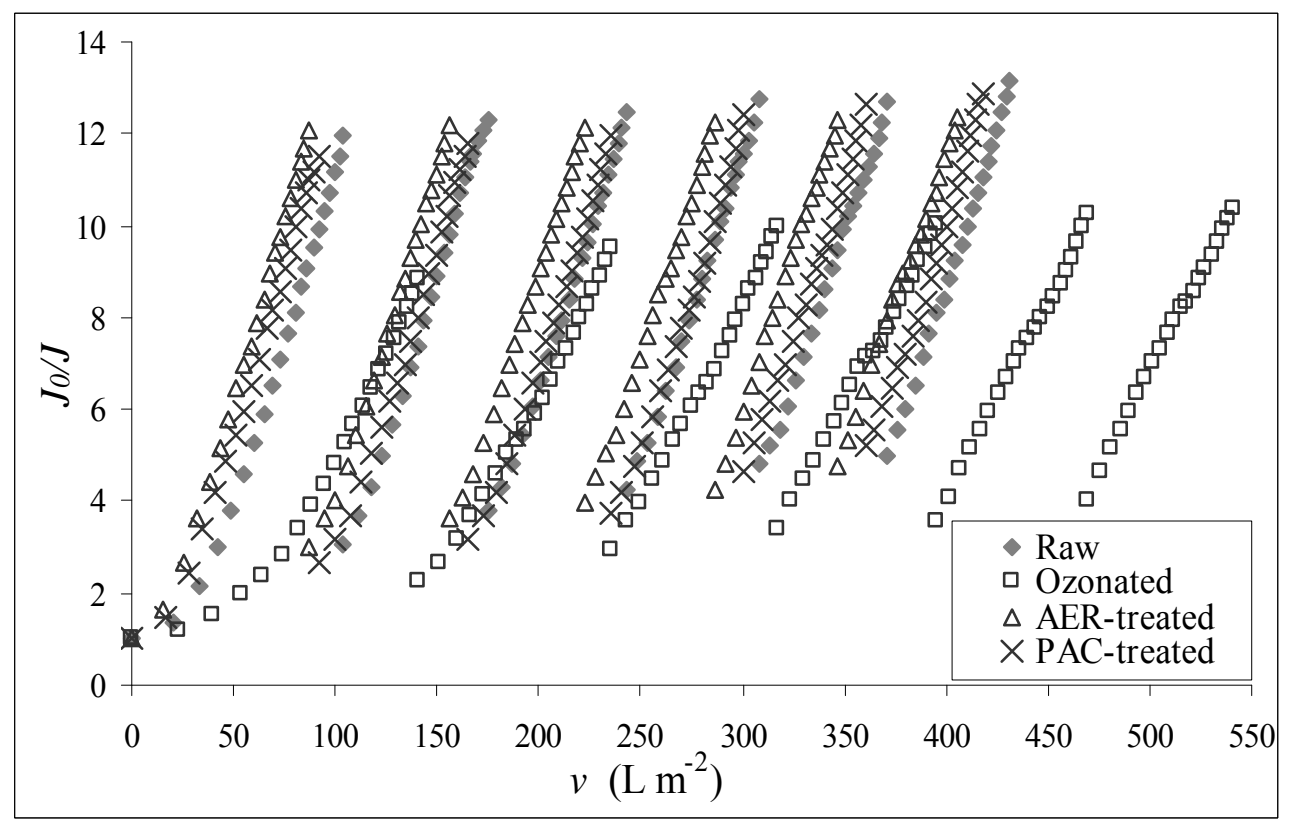

Fig. 5. Flux data for multi-cycle MF of the raw and variously treated effluent 
SUPPLEMENTARY MATERIAL

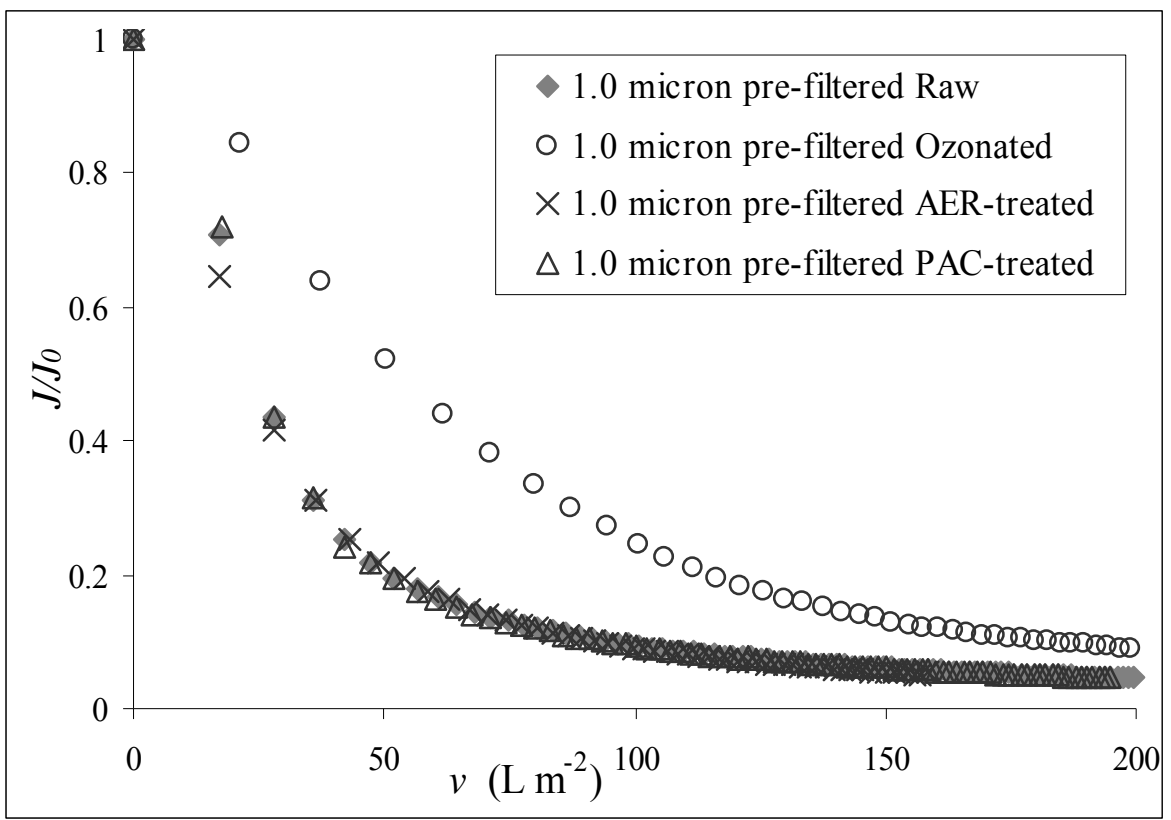

Fig. A.1. Flux data for MF of the raw and pre-treated effluent samples after the removal of particles larger than $1.0 \mu \mathrm{m}$ 

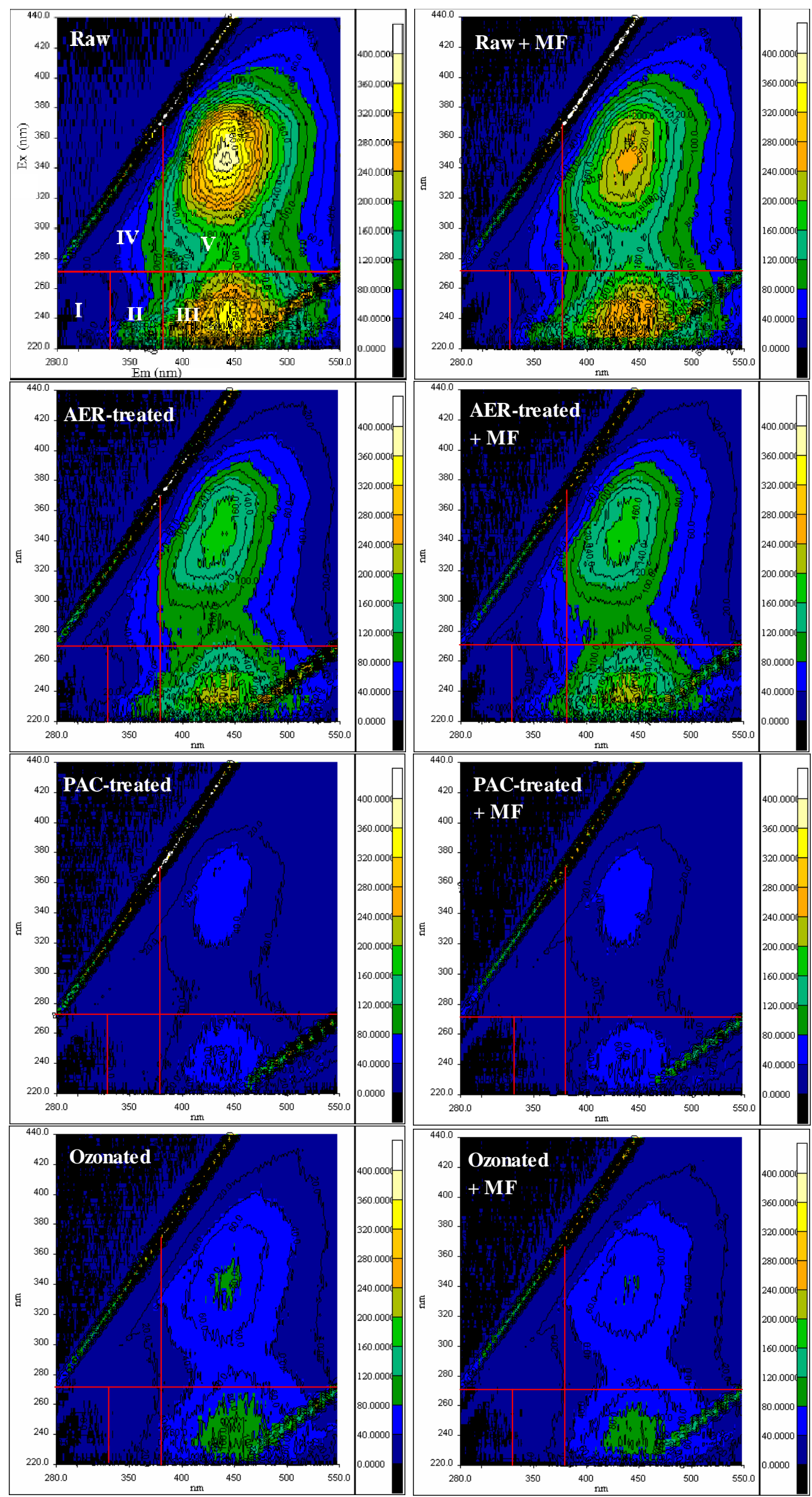

Fig. A.2. Fluorescence EEMs of the raw and variously treated effluent 